\title{
Wear of Composites by Abrasives of Varying Hardness*
}

H. M. ROOTARE, J. M. POWERS and R. G. CRAIG

School of Dentistry, The University of Michigan, Ann Arbor, Michigan 48109

The relationship between the wear of three composite resins and the hardness of the abrasive was studied by a two-body abrasion test. The wear rates of the composites increased linearly with $a b$ rasive hardness from 530 to $2080 \mathrm{KHN}$. Measurement of the slope of the wear rate versus abrasive hardness over this range provided a sensitive method for ranking the composites.

J Dent Res 58(3):1097-1100, March 1979

\section{Introduction.}

Loss of anatomic form or wear has been documented as a contraindication for the routine use of Class II composite resin restorations ${ }^{1}$. The wear of various commercial restorative resins and amalgam has been measured in vitro by a two-body abrasion test that used silicon carbide paper as the surface on which samples were abraded ${ }^{2}$. Rankings obtained from this test appeared to correlate with the one-year data of Leinfelder and his associates ${ }^{3}$. The sensitivity of the two-body abrasion test, however, might be improved by the use of abrasives lower in hardness than silicon carbide.

The purpose of this study was to measure the wear of three commercial composite restorative materials by a two-body abrasion test in which five abrasives with different values of Knoop hardness were used.

\section{Materials and methods.}

Three composite resins ( $\mathrm{A}, \mathrm{AR}$, and $\mathrm{S}$ ) were evaluated for wear rate as a function of hardness of the abrasive in a two-body abrasion test. Product names, batch num-

\footnotetext{
Received for publication March 6, 1978

Accepted for publication April 4, 1978

*This investigation was supported in whole by Research Grant DE-03416 from the National Institute of Dental Research, National Institutes of Health, Bethesda, Maryland 20014

The cooperation of Mr. Jerry Lipkin of RDC Industries, Inc., Philadelphia, PA 19132 for production of experimental abrasive sheets is acknowledged.
}

bers, and manufacturers of the composites are given in Table 1.

The composites were mixed according to manufacturer's instructions, and cylindrical specimens $(6 \mathrm{~mm}$ in diameter by $12 \mathrm{~mm}$ long) were made in stainless steel dies and stored in water at $37 \mathrm{C}$ for 24 hours before testing. Each specimen was held stationary in a jig under a normal load of $5 \mathrm{~N}$ (a stress of $0.18 \mathrm{MPa}$ ). Abrasion was caused by an abrasive sheet attached to the table of a surface grinder. Each specimen was abraded at a speed of $0.25 \mathrm{~cm} / \mathrm{sec}$ for a distance of $10 \mathrm{~m}$ with each pass of $25 \mathrm{~cm}$ made on a fresh abrasive surface. The rubbing surfaces were continually flushed with distilled water at room temperature $(25 \mathrm{C})$ to remove wear debris.

Codes, batch numbers and manufacturers of the abrasives used are listed in Table 1. These abrasives were selected to cover the Knoop hardness range from $530 \mathrm{KHN}$ (CV) to $2480 \mathrm{KHN}$ (SC). Particle size distribution and the median particie size of abrasive powders were determined using a particle size analyzer* by detection of sedimentation rates of particles in a slurry by a finely collimated beam of low energy x-rays. These non-porous particles were further characterized with respect to the void volume and surface area by mercury porosimetry. $\dagger$ True densities of the abrasives were determined by an automatic pycnometer $\S$ using helium. The abrasive powders then were attached to paper or plastic sheets as described in Table 1.

Six replications were obtained for each material with each of the five abrasives. Wear was determined by measurement of the change in length of the specimen with a micrometer accurate to $0.001 \mathrm{~mm}$. The data were reported as volume loss per unit

*Sedigraph 5000, Micromeritics Instrument Corp., Norcross, GA 30093.

$\dagger$ Aminco, Model 5-7125B, American Instrument Co., Silver Spring, MD 20910.

$\S$ Model 1310, Micromeritics Instrument Corp., Norcross, GA 30093. 
TABLE 1

CODE, BATCH NUMBER AND MANUFACTURER OF COMPOSITE RESINS AND ABRASIVES

\begin{tabular}{|c|c|c|c|}
\hline Code & Materials & Batch No. & Manufacturer \\
\hline \multicolumn{4}{|c|}{ Composite Resins: } \\
\hline A & Adaptic & $\begin{array}{l}\text { base-7E019 } \\
\text { catalyst-7E019 }\end{array}$ & $\begin{array}{l}\text { Johnson \& Johnson } \\
\text { Dental Products Div. } \\
\text { East Windsor, NJ } 08520\end{array}$ \\
\hline $\mathrm{AR}$ & Adaptic Radiopaque & $\begin{array}{l}\text { base-6L } 103 \\
\text { catalyst-6L103 }\end{array}$ & Johnson \& Johnson \\
\hline$S$ & Simulate & $\begin{array}{l}\text { base- } 771311 \\
\text { catalyst- } 772307\end{array}$ & $\begin{array}{l}\text { Kerr Mfg. Co. } \\
\text { Romulus, MI } 48174\end{array}$ \\
\hline \multicolumn{4}{|c|}{ Abrasives*: } \\
\hline $\mathrm{SC}$ & $\begin{array}{l}\text { Silicon Carbide } \\
\quad(600 \text { Grit })\end{array}$ & $40-6415-600-080$ & $\begin{array}{l}\text { Buehler Ltd. } \\
\text { Evanston, IL } 60204\end{array}$ \\
\hline$A L$ & Alumina (LPA-150) & 1665 & $\begin{array}{l}\text { RDC Industries, Inc. } \\
\text { Philadelphia, PA } 19132\end{array}$ \\
\hline $\mathrm{G}$ & Garnet & 97,241 & $\begin{array}{l}\text { Barton Mines Corporation } \\
\text { North Creek, NY }\end{array}$ \\
\hline $\mathrm{Q}$ & Quartz $(-200 \mathrm{Mesh})$ & - & $\begin{array}{l}\text { American Fused Quartz Co. } \\
\text { Montville, NJ } 07045\end{array}$ \\
\hline $\mathrm{CV}$ & $\begin{array}{l}\text { Glass ( } \mathrm{Li}, \mathrm{Al}, \mathrm{SiO}_{2} ; \\
\text { CER-VIT, T-1000) }\end{array}$ & 74,351 & $\begin{array}{l}\text { Owens-Illinois, Inc., Electronic } \\
\text { Materials, Toledo, OH } 43601\end{array}$ \\
\hline
\end{tabular}

*The experimental sheets of G, Q, and CV were made by RDC Industries, Philadelphia, PA 19132 on $0.13 \mathrm{~mm}$ thick plastic sheet. Sheets of SC and AL were available commercially as indicated.

travel $\left(\mathrm{mm}^{3} / \mathrm{mm}\right)$. Mean values were compared with Tukey intervals ${ }^{4}$ computed from analysis of variance. ${ }^{5}$

\section{Results.}

Particle size distributions of the abrasive powders are shown in Figure 1. All of the powders except $Q$ had distributions where 98 percent of the particles were smaller than $26 \mu \mathrm{m}$. The shapes of the abrasive particles are shown in scanning electron photomicrographs in Figure 2. Values of hardness and other physical properties of the abrasives are listed in Table 2.

The wear rates determined for the three composite resins on the five abrasive sheets are listed in Table 3 and are plotted versus Knoop hardness of the abrasive in Figure 3. The wear rates of the composites varied linearly with hardness of the abrasive between 530 and $2080 \mathrm{KHN}$ and then increased dramatically for the silicon carbide abrasive ( $2480 \mathrm{KHN})$. The slopes between 530 and $2080 \mathrm{KHN}\left(10^{-7} \mathrm{~mm}^{3} / \mathrm{mm} / \mathrm{KHN}\right)$ for $\mathrm{A}, \mathrm{AR}$, and $\mathrm{S}$ were $0.50,0.87$, and 2.39 , respectively. The values of the correlation coefficient ( $r$ ) computed from an analysis of regression $^{7}$ were $0.990,0.995$, and 0.988 for $A, A R$, and $S$, respectively. The critical value of $r$ above which the hypothesis of independence of wear rate and abrasive hardness could be rejected was 0.950 at the 95 percent level of confidence.

The aforementioned slopes of wear rate versus Knoop hardness of the abrasives were plotted as a function of the fraction of glass in the filler for the three composite resins as shown in Figure 4 . The curve was linear and the values of the slope (plotted on the ordinate) increased with increasing

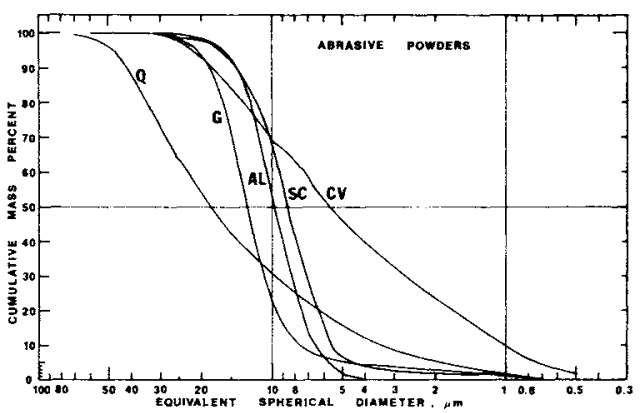

Fig. 1. - Comparison of particle size distribution of five abrasive powders. 


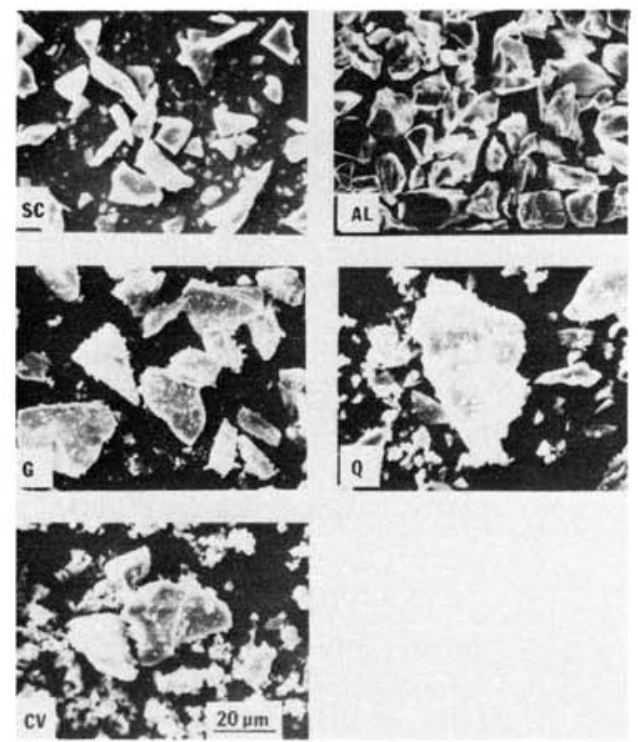

Fig. 2 - SEM photomicrographs of the abrasive powders.

glass content in the filler of the composite from $A$ to $A R$ to $S$, respectively.

\section{Discussion.}

The ratio of the wear rate of the three composites (S:AR:A) as measured on the silicon carbide abrasive was 1.98:1.14:1.00. The ratio of the slope of wear rate versus abrasive hardness ( $\mathrm{S}: \mathrm{AR}: \mathrm{A})$ over the range of 530 to $2080 \mathrm{KHN}$ was $4.78: 1.74: 1.00$. Although both methods rank the composites tested in the same order, the latter method where the slope of wear rate versus abrasive hardness is measured is more sensitive.

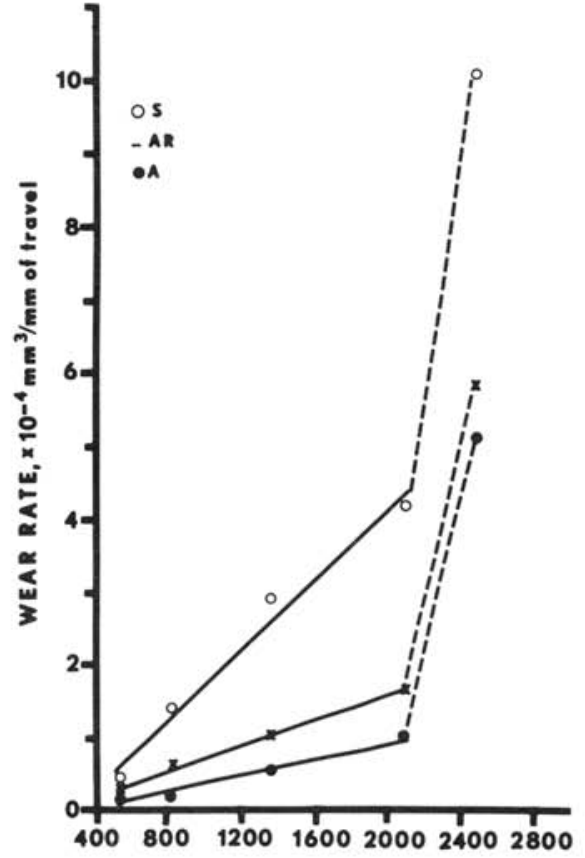

KNOOP HARDNESS OF ABRASIVE, $\mathrm{kg} / \mathrm{m} \mathrm{m}^{2}$

Fig. 3 - Wear rate versus Knoop hardness of the abrasive for three composites.

In this study it was assumed that hardness was the most important difference among the abrasives in their ability to cause wear. The change in slope of wear rate versus Knoop hardness of the abrasive (indicated in Figure 3 by the dashed line) may have been caused by a dramatic change in the mode of surface failure of the composites when the hardness of the abrasive increased from 2080 to 2480 KHN. A second explanation may be that the density

TABLE 2

PHYSICAL PROPERTIES OF ABRASIVE POWDERS

\begin{tabular}{cccccc}
\hline \hline Code & $\begin{array}{c}\text { Knoop } \\
\text { Hardness } \\
\mathrm{kg} / \mathrm{mm}^{2}\end{array}$ & $\begin{array}{c}\text { Median } \\
\text { Particle } \\
\text { Size, } \mu \mathrm{m}\end{array}$ & $\begin{array}{c}\text { Void } \\
\text { Volume, } \\
\mathrm{cm}^{3} / \mathrm{g}\end{array}$ & $\begin{array}{c}\text { Surface } \\
\text { Area, } \\
\mathrm{m}^{2} / \mathrm{g}\end{array}$ & $\begin{array}{c}\text { Density by He, } \\
\mathrm{g} / \mathrm{cm}^{3}\end{array}$ \\
\hline $\mathrm{SC}$ & 2480 & 8.5 & 0.465 & 0.845 & $3.182(0.002)$ \\
$\mathrm{AL}$ & 2080 & 9.8 & 0.341 & 0.449 & $3.966(0.004)$ \\
$\mathrm{G}$ & 1360 & 12.8 & 0.309 & 0.510 & $3.881(0.001)$ \\
$\mathrm{Q}$ & 820 & 18.2 & 0.374 & 0.370 & $2.710(0.006)$ \\
$\mathrm{CV}$ & 530 & 5.7 & 0.628 & 2.85 & $2.473(0.004)$ \\
\hline
\end{tabular}


TABLE 3

WEAR RATE OF MATERIALS FOR VARIOUS ABRASIVES

WEAR RATE, $10^{-4} \mathrm{~mm} 3 / \mathrm{mm}$ of travel

\begin{tabular}{cccccc}
\hline ABRASIVE CODE & SC & AL & G & Q & CV \\
\hline $\begin{array}{c}\text { KNOOP HARDNESS, } \\
\text { kg/mm } 2\end{array}$ & 2480 & 2080 & 1360 & 820 & 530 \\
\hline Material: & & & & & \\
A & $5.09(0.17)^{*}$ & $0.96(0.07)$ & $0.55(0.03)$ & $0.25(0.04)$ & $0.22(0.03)$ \\
AR & $5.83(0.44)$ & $1.65(0.06)$ & $1.02(0.31)$ & $0.63(0.04)$ & $0.23(0.06)$ \\
S & $10.06(0.48)$ & $4.18(0.32)$ & $2.92(0.41)$ & $1.37(0.34)$ & $0.40(0.14)$ \\
\hline
\end{tabular}

* Mean value of six replications with standard deviation in parentheses. Tukey intervals computed from analysis of variance at the $95 \%$ level of confidence were 0.16 for comparisons among composites and 0.19 for comparisons among abrasives.

of the abrasive on the commercial silicon carbide (SC) paper may have been greater than that on the other papers $(A L, G, Q$ and $\mathrm{CV}$ ) produced by a different manufacturer.

\section{Conclusions.}

The relationship between the wear of three commercial composites and the hardness of the abrasive over a range from 530 to $2480 \mathrm{KHN}$ was studied by a twobody abrasion test. The wear rates of the composites increased linearly with abrasive

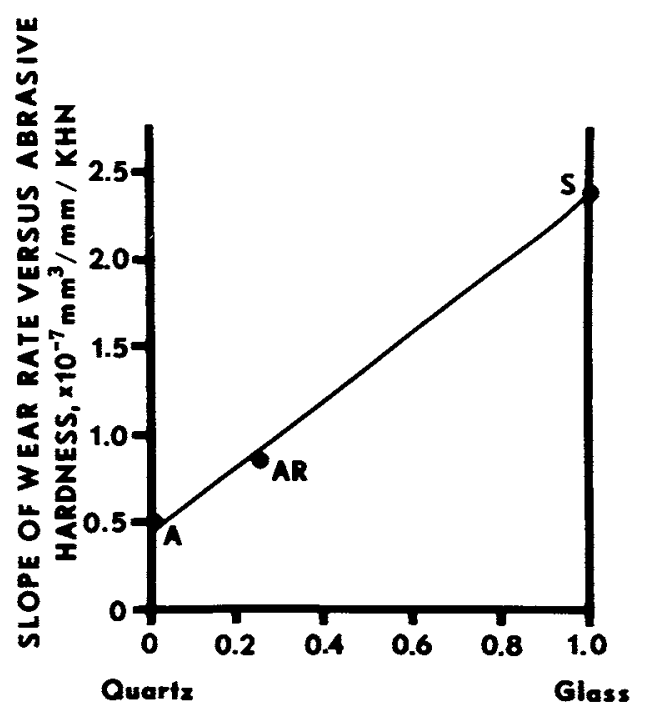

\section{FRACTION OF GLASS}

Fig. 4 - Slope of wear rate versus abrasive hardness plotted as a function of the fraction of glass in the filler. hardness from 530 to $2080 \mathrm{KHN}$ but then increased dramatically when a silicon carbide abrasive $(2480 \mathrm{KHN})$ was used. The addition of glass to the quartz filler reduced the resistance of the composites to two-body abrasion in a linear fashion. Ranking the wear of composites by measuring the slope of the wear rate versus abrasive hardness curve over a range of abrasive hardness from 530 to $2080 \mathrm{KHN}$ appears to be more sensitive than comparison of wear rates measured on silicon carbide abrasive alone.

\section{REFERENCES}

1. CRAIG, R. G.; and POWERS, J. M.: Wear of dental tissues and materials, Internat. Dent. $J$. 26:121-133, 1976 .

2. POWERS, J. M.; ALLEN, L. J.; and CRAIG, R. G.: Two-body abrasion of commercial and experimental restorative and coating resins and an amalgam, JADA 89:1118-1122, 1974.

3. LEINFELDER, K. F.; SLUDER, T. B.; STOCKWELL, C. L.; STRICKLAND, W. D.; and WALL, J. T.: Clinical evaluation of composite resins as anterior and posterior restorative materials, J. Prosth. Dent. 33:407-416, 1975.

4. GUENTHER, W. C.: Analysis of variance, Englewood Cliffs, N. J., Prentice-Hall, Inc., 1964 , p. 141.

5. DALBY, JOHN, Programmer: BMD8V-Analysis of variance, Ann Arbor, Statistical Research Laboratory, University of Michigan, 1968.

6. WEAST, R. C.; SHELBY, S. M.; and HODGMAN, C. D., eds.: Handbook of chemistry and physics, 46 th ed., Cleveland, Ohio, The Chemical Rubber Co., 1965-1966, p. F-15.

7. University of Michigan, Statistical Research Laboratory: A manual of elementary statistics using MIDAS, Ann Arbor, Statistical Research Laboratory, 1975, p. 301. 